J. Kornilova, PhD stud. (Law)

Taras Shevchenko National University of Kyiv, Kyiv, Ukraine

\title{
THE STRUCTURE OF THE STATE ECONOMIC POLICY OF UKRAINE IMPLEMENTATION
}

The article is devoted to the analysis of the structure of the state economic policy of Ukraine implementation.

The research uses a wide range of general and special legal methods and techniques of scientific research, in particular: analysis and synthesis, induction and deduction; comparative legal, structural-functional, formal-dogmatic methods.

As a result of the study, the author substantiates the scientific position that determining the structure of economic policy of Ukraine and its elements, ensuring their coordinated interaction is a priority in the effective functioning of this area of public policy of Ukraine. Unfortunately, the current model of Ukraine's state economic policy in Ukraine is not able to ensure its effectiveness. As a model, it is proposed to take the one developed by German scientists, which provides for the consistent interaction of such elements of the structure of public policy as a strategy, a plan, the implementation of the plan and a report on the implementation of the plan.

This model of implementation of economic policy of Ukraine should be the basis for public administration of the economy of Ukraine.

Legal support of public administration by economic policy of Ukraine needs to be streamlined and strengthened. According to the author, this goal can be achieved through the adoption, first of all, of the National Strategy for Economic Development of Ukraine, which will become a strategic document. It should specify the purpose, goals, strategic objectives and principles of state economic policy of Ukraine. Based on it, plans for the implementation of this National Strategy should be developed as tactical documents. They should identify step-by-step measures to implement this strategy.

Keywords: economy, state policy, administrative law, a structure, legislation.

Bulletin of Taras Shevchenko National University of Kyiv. Legal Studies, 2020; 2 (113): 28-32

УДК: 347.9

DOI: https:doi.org/10.17721/1728-2195/2020/2.113-6
ISSN 1728-2195

(C) Taras Shevchenko National University of Kyiv, Publishing center "Kyiv University", 2020

А. Коцюруба, асп.

ORCID ID: 0000-0003-4283-2078

Київський національний університет імені Тараса Шевченка, Київ, Україна

\section{ПРИМИРНІ ПРОЦЕДУРИ В ЦИВІЛЬНОМУ СУДОЧИНСТВІ УКРАїНИ}

Краще погана мирова угода, ніж хорощий процес (французьке прислів'я)

Досліджено правову природу та проведено аналіз нормативної основи закріплення двох судових примирних процедур цивільного судочинства: мирової угоди та процедури врегулювання спору за участю судді.

Звертається увага на гостру необхідність дослідження судових примирних процедур у цивільному процесі України. Оцінено їхню функціональну дієвість в умовах сьогодення, виявлено окремі проблемні аспекти законодавчого регулювання цих інститутів і висунуто пропозиції щодо усунення недоліків та можливого переформатування цих процедур, що, імовірно, сприяли б ефективному і швидкому розв'язанню цивільних спорів.

Неодноразово наголошено, що розвиток і використання примирних процедур є питанням майбутнього для всієї системи правосуддя України. Визначено за необхідне створювати достатню теоретичну основу для пошуку нових чи трансформації існуючих способів регулювання цивільних спорів таким чином, щоб вони розв'язували існуючі проблеми судової системи України та сприяли формуванню "ідеального правосуддя".

Проведено ґрунтовний аналіз норм Цивільного процесуального кодексу Украӥни, що регулюють порядок застосування мирової угоди і процедури врегулювання спору за участю судді; висловлено низку зауважень і пропозицій до чинного цивільного процесуального законодавства України.

Запропоновано можливі способи переформатування законодавчо визначених механізмів розв'язання спору, які 6 частково чи повністю розв'язували завдання, покладені законодавцем на судові примирливі процедури. Сформульовано висновки щодо позитивних і негативних явищ, які викликало реформування цивільного процесуального законодавства в частині досліджуваних примирних процедур.

Ключові слова: цивільне судочинство, примирні процедури, мирова угода, урегулювання спору за участю судді, медіація, судова медіація.

ВСтУп. Розв'язання спору шляхом спільного пошуку сторонами консенсусу у справі $€$ ідеальним варіантом мирного врегулювання. Цивільний процесуальний кодекс України (надалі - ЦПК) фрактично визначає два шляхи врегулювання спору шляхом використання процедури примирення: мирова угода й урегулювання спору за участю судді. Кожен із цих інститутів має певні особливості, але також вони мають і спільну ціль розв'язання цивільно-правового спору на підставі взаємних поступок у зручний для учасників процесу спосіб і мінімальні терміни.

Аналіз останніх досліджень і публікацій. Процедури судового примирення з кінця 2017 року стали як ніколи частим об'єктом наукової уваги. Серед новел найбільш інноваційною стало впровадження процедури врегулювання спору за участі судді. Щодо сутності та проблематики цього допоміжного інституту розв'язання спорів уже опублікована велика кількість наукових робіт, зокрема О.Є. Блажівської, Н. В. Василини,
Н. Л. Бондаренко-Зелінської, Н. О. Кіреєвої, Д. С. Коноваленко, А. О. Лесько, Д.Д. Луспеника, О. Ю. Одосій, Л. Д. Романадзе, Т. А. Цувіної та ін. Однак попри значні теоретичні напрацювання тема залишається особливо актуальною і потребує подальшого розвитку та напрацювання механізмів удосконалення цивільного процесуального законодавства в частині судових примирних процедур.

Звичайно, цивільним процесуальним законодавством передбачені альтернативні судовій процедурі способи розв'язання цивільних спорів між учасниками правовідносин: переговори, третейське судочинство, міжнародний комерційний арбітраж. Інститут медіації в Україні вже досить довго досліджується, розробляється і практикується, проте процедурно визначений лише проєктом закону [2], у якому передбачено медіацію як позасудову процедуру врегулювання спору. У будь-якому разі медіація, як і інші досудові процедури регулювання спору, є добровіль- 
ною процедурою і передусім залежить від спільного бажання сторін у її використанні.

Переважна більшість науковців-практиків і суддів звертає увагу на безперечну корисність та ефективність використання судових примирних процедур. Зокрема, суддя КЦС ВС Ольга Ступак зазначає: "Найкращий спосіб розв'язання спорів про поділ майна подружжя укласти мирову угоду". Вона звертає увагу на те, що можна укласти договір про поділ і без суду, звернувшись до нотаріуса. Якщо ж не дійшли згоди на цьому етапі, то суд може посприяти сторонам у розв'язанні спірних питань на стадії врегулювання спору за участю судді. А далі можна укласти мирову угоду як на стадії розгляду справи в суді першої, так і в апеляційній або касаційній інстанції [3].

Однак попри наявність великої кількості способів розв'язання спорів на досудовому етапі, на жаль, українці з різних причин ними вкрай рідко користуються. В Україні розгляд спорів у судах $є$ основною формою захисту своїх прав та інтересів, що яскраво демонструє надзвичайно висока кількість позовних заяв, що надходять у суди.

На невикористання позасудових і судових примирних процедур урегулювання спорів впливає багато різних факторів, зокрема неусвідомлення потенційної корисності й ефективності альтернативного розв'язання спорів, недостатнє роз'яснення в суспільстві переваг альтернативних моделей розв'язання спорів, недовіра судів до такої процедури судового примирення, особливості ментальності українців, відсутність спеціально підготовлених посередників, мала дослідженість альтернативних способів розв'язання спорів у цивільному судочинстві. Усі ці проблеми потребують розв'язання, але в будь-якому разі - це довготривалий процес, результати якого будуть відчутні не одразу. Наш законодавець провів реформування процесуальних кодексів, обравши шлях запровадження кардинально нового в цивільне процесуальне законодавство без попередньої підготовки суддів та учасників судового процесу до цього. У зв'язку з цим інститут урегулювання спору за участю судді працює зовсім не так, як того очікували. Тому на сьогодні необхідно забезпечити виконання таких основних функцій примирних процедур: 1) розроблення зручного й ефективного механізму їх використання учасниками судового процесу для захисту своїх прав та інтересів; 2) розвантаження судів для забезпечення винесення якісних і правомірних рішень.

Метою статті $€$ аналіз існуючих судових примирних процедур у цивільному судочинстві задля напрацювання пропозицій і рекомендацій до цивільно-процесуального законодавства України.

ВИКЛАД ОСНОВНОГО МАТЕРІАЛУ. Мирова Угода $€$ вираженням взаємного волевиявлення сторін, що спрямоване на розв'язання спору між ними на основі компромісу та припинення його подальшого судового розгляду [4, с. 305]. Чинним ЦПК визначено, що мирова угода має стосуватися лише прав та обов'язків сторін (у старій редакції ЦПК обов'язковою була прив'язка до предмета спору), тобто тепер мирова угода може виходити за межі предмета спору, якщо цим не будуть порушені права та інтереси третіх осіб (ч. 1 ст. 207 ЦПК). Мирова угода оформлюється спільною письмовою заявою на будь-якій стадії судового процесу. Укладена сторонами мирова угода в обов'язковому порядку затверджується ухвалою суду, у резолютивній частині якої зазначаються ії умови. Сторони у мировій угоді обов'язково мають передбачити розміри, порядок і терміни виконання зобов'язань боржника, а також відстрочку чи розстрочку або прощення (списання) боргів чи їхньої частини. Додатково мирова угода може містити положення щодо умов виконання зобов'язань боржника третіми особами та задоволення вимог кредиторів іншими способами, що не суперечать закону.

Суд зобов'язаний роз'яснити сторонам наслідки ухвалення рішення у зв'язку з укладенням сторонами мирової угоди, зокрема неможливість повторного звернення до суду із приводу спору між тими самими сторонами, про той самий предмет і з тих самих підстав; обов'язок добровільно виконувати зобов'язання, визначені мировою угодою, і можливість її примусового виконання [4, с. 306].

Особливої уваги потребує питання щодо умов виконання мирової угоди. Чинним ЦПК передбачено, що виконання мирової угоди здійснюється особами, які її уклали, а ухвала про затвердження мирової угоди є виконавчим документом (ст. 208 ЦПК). Це означає, що в разі невиконання умов мирової угоди однією зі сторін інша сторона має право звернутися до приватного чи державного виконавця щодо примусового ії виконання. Тому крім вимог, визначених ст. 260 ЦПК, ухвала суду про затвердження мирової угоди має відповідати й вимогам ст. 4 ЗУ "Про виконавче провадження".

Держава всіляко має сприяти використанню інституту мирової угоди. Одним із таких заохочень стало положення щодо розподілу судових витрат у разі укладення мирової угоди, а саме - повернення позивачу половини сплаченого ним при поданні позову судового збору (ст. 142 ЦПК). Безперечно, такі новели були необхідними для інституту мирових угод при їх подальшій реалізації.

Урегулювання спору за участю судді. Однак найбільш дискусійним стало запровадження інституту врегулювання спору за участю судді, який фрактично змінює підхід до здійснення правосуддя в Україні. Цей інститут поєднує в собі традиційне правосуддя з альтернативним способом розв'язання спору (медіацією), направлений на сприяння оперативному, об'єктивному та компетентному розв'язанню спорів на засадах примирення сторін і покликаний зменшити судове навантаження на суддів і скоротити час на розгляд справ. Сутність цього інституту полягає в тому, що за наявності взаємної згоди сторін, до початку розгляду справи по суті, може бути проведене таке судове примирення.

Розділяємо підходи таких науковців щодо сутності процедури врегулювання спору за участю судді, як Л. Д. Романадзе, що цей інститут є новою в українській практиці гібридною примирливою процедурою, але не $\epsilon$ медіацією [5, с. 3]; Н. О. Кіреєвої та Є. П. Приймак, що цей інститут $€$ судовим примиренням [6, с. 81]; О. Є. Блажівської, яка називає закріплену в законодавстві України процедуру врегулювання спору за участю судді квазімедіацією [7, с. 52]. Проте не так важливо, як ми охарактеризуємо цю процедуру, адже у ЦПК вона вже названа i регламентована, набагато важливіше з'ясувати, чи ця процедура виконує завдання, покладені на неї законодавцем.

Питання щодо врегулювання спору за участю судді вирішується на етапі підготовчого засідання за пропозицією судді при обов'язковій згоді сторін на її застосування (п. 14 ч. 2 ст. 197 ЦПК). Варто погодитися 3 О.Р. Кібенко, яка зазначає, що внесення пропозиції для сторін щодо процедури врегулювання спору за участю суді $\epsilon$ не правом, а обов'язком суду [8], тобто суддя повинен запропонувати сторонам таку процедуру розгляду справи, але перейти до неї можливо лише за спільної згоди сторін.

Хоч подібна модель альтернативного розв'язання спорів активно практикується в багатьох інших держа- 
вах (Німеччині, Австрії, Італії, Швеції, США, Канаді), а результати практики її використання свідчать про безперечну ефективність, проте в Україні ця процедура примирення викликає цілу низку запитань. У реаліях сьогодення покладення ролі примирителя на кожного суддю, у провадженні якого перебуває справа, важко назвати доцільним нововведенням.

Одні 3 перших статистичних даних щодо практики використання врегулювання спору за участю судді були озвучені на II Судовому фрорумі суддею Господарського суду Одеської області Юлією Бездолею, де вона навела таку статистику: станом на 15 березня 2019 року в Одесі було призначено 17 справ до розгляду врегулювання спорів за участю судді, з них 2 - успішно розглянуті, а в 15 справах проведено заміну складу суду [9]. У пошуку ЄДРСР зустрічаються лише поодинокі ухвали щодо припинення врегулювання спору за участю судді у зв'язку з укладенням сторонами мирової угоди. Усе це свідчить про те, що сторони використовують зазначену процедуру переважно не в цілях розв'язання спору, а як механізм зловживання процесуальними правами. На нашу думку, усі очікування щодо функціонування інституту врегулювання спору за участю судді в цивільному судочинстві України себе не виправдали, адже минуло вже більше двох років після появи цієї примирної процедури, а показників успішної практики ії використання дуже мало, навантаження на суди не зменшилось, а випадки зловживання, пов'язані з використанням цього інституту, переважають над тими справами, у яких він сприяв розв'язанню спору.

Одна із пропозицій удосконалення процедури врегулювання спору за участю судді висловлена Н. Л. Бондаренко-Зелінською і полягає в можливості повернення позивачу половини судового збору у випадку укладення мирової угоди як наслідку розв'язання спору його врегулюванням за участю судді [10, с. 68]. Вважаємо, що це положення вже реалізоване законодавцем, адже відповідно до п. 4 ч. 1 ст. 204 ЦПК один із варіантів закінчення процедури врегулювання спору за участю судді - це укладення мирової угоди. У цьому випадку про припинення врегулювання спору за участю судді видається ухвала, яка оскарженню не підлягає, i тоді суддя вирішує питання про поновлення провадження у справі. На цей випадок також розповсюджується норма щодо повернення половини судового збору, адже мирова угода може бути укладена на будь-якій стадії судового процесу.

Проведення врегулювання спору за участю судді не допускається у разі, якщо у справу вступила третя особа, яка заявляє самостійні вимоги щодо предмета спору (ч. 2 ст. 201 ЦПК). Хоч відповідно до ст. 52 ЦПК такі особи користуються правами та обов'язками позивача, але відповідне положення ст. 201 ЦПК слід визнати абсолютно обґрунтованим, адже результат такого врегулювання не має порушувати права та інтереси інших осіб, які не $є$ стороною спору.

Положення щодо обмеження проведення процедури врегулювання спору за участю судді у 30 днів зо дня постановлення ухвали й заборону повторного її проведення слід розцінювати як виправдані нововведення, що запобігатимуть затягуванню розгляду справи.

Численним зауваженням як теоретичного характеру, так і з практики застосування цього інституту піддаються положення глави 4 ЦПК.

По-перше, найбільше запитань виникає до визначення статусу судді як основного організатора процедури врегулювання спору за участю судді, адже йому необхідно поєднувати два досить різні за своєю природою стани: судді та медіатора. У державах, де працює інститут медіації, медіатором є спеціально підготовлений нейтральний і незалежний посередник, який, дотримуючись певних процедур, допомагає сторонам спору в його врегулюванні, організовує та проводить медіацію. Суддя ж виходить із позиції застосування права, а не шляхом спонукання сторін до досягнення компромісу. Відповідно, тепер судді мають володіти комплексом особливих умінь і навичок, яких раніше ніколи не здійснювали в процесі. Тепер суддям, які звикли судити "за буквою закону", потрібно перелаштуватися на новий лад і змінити підхід до типового суддівства. Чи всі зможуть це зробити? Чи кожен суддя бажає й може виконувати функцію примирення? Чи достатньо в Національній школі суддів України тренерів відповідної кваліфікації та інших ресурсів для централізованого навчання? Як державі потрібно мотивувати суддю, щоб він обирав саме цей, новий для нашої судової системи, спосіб розв'язання спору, а не звичну йому процедуру?

Далеко не кожний суддя володіє комплексом умінь і особистих навичок для успішного розв'язання справи мирним шляхом, навіть якщо він пройшов спеціальне навчання. Недостатнє законодавче визначення процедури врегулювання спору за участю судді, наділення таким правом кожного судді, до провадження якого надходить справа, неналежна підготовка суддів до її проведення та інші пов'язані з цим причини зумовили лише поодинокі випадки ефективного використання цього інституту на практиці.

По-друге, чому саме суддя, який відкрив провадження за справою, має здійснювати врегулювання спору між сторонами в цивільному процесі [6, с. 81]? Більш доречним було б, щоб цю процедуру проводив суддя-медіатор, який бажає і здатний (що визначатиметься за результатами закінчення навчання) проводити процедуру врегулювання спору за участю судді, або ж такою особою міг би бути спеціально підготовлений посередник. Такими посередниками могли б залучатися адвокати, юристи, судді у відставці, які б пройшли спеціальну підготовку для отримання відповідних умінь для здійснення функції судового примирення, виходячи не тільки з норм права, але й володіючи психологічними та організаційними навиками, необхідними для врегулювання спору.

По-третє, законодавчі положення, що регламентують процедуру використання цього інституту, містять низку дискусійних положень, зокрема:

1. Незрозумілою $€$ позиція законодавця, з одного боку, заборонити судді надавати сторонам юридичні поради та рекомендації, а з іншого - суддя має право запропонувати їм можливий шлях мирного врегулювання спору. Без сумніву, шлях мирного врегулювання спору, який повинен запропонувати суддя, передбачає юридичні поради та рекомендації [7, с. 51].

2. Поза увагою законодавця залишилось питання участі адвоката при проведенні процедури врегулювання спору за участю судді.

3. Поділяємо позицію Н. Л. Бондаренко-Зелінської щодо необхідності розширення переліку осіб, які можуть залучатися до участі в нарадах. Наразі ч. 8 ст. 203 ЦПК України до складу таких осіб віднесено тільки перекладача, у той час як практика застосування примирних процедур у позасудовому порядку свідчить про доцільність залучення й інших фахівців (наприклад психолога у справах щодо прав дитини) [10, с. 63].

Також викликає певні зауваження положення щодо абсолютної конфіденційності при проведенні процедури врегулювання спору за участю судді, яка відповідно до ст. 203 ЦПК може бути у формі спільних нарад або ж закритої наради за ініціативою судді з кожною зі сторін 
окремо. Сторони мають право брати участь у таких нарадах у режимі відеоконференції. Уся отримана інформація в процесі ії проведення не може бути розголошена, протокол не ведеться та не здійснюється фріксування. До сторони, яка здійснить аудіо-, фото- або відеофіксацію процедури врегулювання спору за участю судді, можуть бути застосовані штрафні санкції, передбачені ст. 149 ЦПК. Важко зрозуміти, чому законодавець установив заборону сторін на фріксацію цієї процедури, адже це прямим чином може призвести до зловживань правами. У цьому питанні варто погодитися із Р. О. Куйбідою, який висловився проти такої заборони, мотивуючи це тим, що за її використання суддя може безперешкодно вимагати у сторін хабар і не боятися відповідальності, оскільки аудіозапис вимагання грошей чи інших благ суддею, навіть якщо такий буде зроблено таємно, не можна буде використати як доказ вчинення ним злочину [11]. О. Р. Зельдіна назвала це запровадження у процесуальні кодекси процедурою узаконення "договірняків" саме з огляду на те, що закриті наради проводяться за ініціативою судді 3 кожною зі сторін окремо [7, с. 50].

Отже, на нашу думку, упровадження інституту врегулювання спору за участю судді в запропонованій редакції ЦПК було надто передчасним. Адже з об'єктивних причин судова влада сьогодні не здатна забезпечити належне його функціонування. Тому виникає логічне запитання: чи потрібна взагалі така модель примирення в чинному законодавстві? В Україні склалася ситуація, що до досудових способів урегулювання спору особи звертаються вкрай рідко. Як показує практика, найефективнішим способом розв'язання спору українці вважають судовий. Тому на рівні законодавства краще удосконалювати саме судові примирні процедури.

Українським законодавством примирні процедури врегулювання спору визначені як право учасників справи. Проте надмірне навантаження на суди, що прямо впливає на якість розв'язання ними спорів, указує на необхідність рішучих змін. Можливий варіант, який би сприяв розв'язанню цих проблем, вбачаємо в запровадженні обов'язкових примирних способів розв'язання спору.

Наприклад, у Сінгапурі із 2012 року всі цивільні спори, що надходять до судів, підлягають обов'язковій попередній спробі розв'язання шляхом застосування медіації, якщо тільки сторони не домовляться про зворотне. Спеціальне положення процесуального законодавства передбачає можливість накладення грошового стягнення на особу, яка безпідставно відмовляється брати участь у процедурі медіації. Також у 23 штатах США закріплена обов'язкова досудова процедура врегулювання спору, без проведення якої суд не приймає позовні заяви [12].

У зв'язку зі всім вищезазначеним автори статті хотіли б запропонувати два способи вдосконалення примирливих судових процедур у цивільному судочинстві України, які нами оцінюються як такі, що сприяли б поліпшенню всієї системи правосуддя в частині судових примирних процедур.

Перший спосіб передбачає вдосконалення інституту мирової угоди шляхом запровадження обов'язкових переговорів до початку підготовчого засідання за участі посередника чи адвоката(ів). На законодавчому рівні його реалізація можлива як пілотного проєкту щодо окремих категорій справ. Зокрема, в ухвалі про відкриття провадження у справі треба визначити в обов'язковому порядку дату, час, місце й особу посередника для попередньої зустрічі сторін (представників сторін) за справою для обговорення можливості врегулювання спору до підготовчого засідання, у результаті чого має бути складений відповідний документ, у якому зазначено, чи дійшли сторони попередньої домовленості щодо спору. До чи під час підготовчого засідання судді має бути переданий документ відповідної форми, що свідчитиме про попередню зустріч сторін і про можливість укладення мирової угоди. За неявку сторін(они) на переговори чи за відсутності такого документа передбачити накладення штрафу на сторони(у). У результаті ж укладення мирової угоди розповсюджуватиметься норма щодо повернення 50 \% сплаченого судового збору.

Ідея такого формату обов'язкових переговорів полягає не в тому, щоб відразу після неї була укладена мирова угода, а в тому, щоб показати сторонам можливі перспективи розвитку справи i, можливо, цим сприяти укладенню мирової угоди надалі.

Другий варіант передбачає часткове поєднання інституту медіації та процедури врегулювання спору за участю судді та, як наслідок, створення інституту судової медіації. У п. 2 ч. 1 ст. 70 ЦПК уже йдеться про інститут медіації: серед осіб, які не можуть бути допитані як свідки, названо осіб, які за законом зобов'язані зберігати в таємниці відомості, що були довірені їм у зв'язку з наданням послуг посередництва (медіації) під час проведення позасудового врегулювання спору, тобто законодавець заклав фундамент для розвитку цього інституту в цивільному судочинстві.

3 огляду на статистику за 2018 р. по двох категоріях сімейних спорів найбільше навантаження судової системи лягає на суди першої інстанції, які ухвалили 110756 рішень про розлучення та 57076 рішень щодо стягнення аліментів. В апеляційних інстанціях було розглянуто 2368 справ про стягнення аліментів та 328 справ про розірвання шлюбів. Верховний суд переглянув 72 справи про розірвання шлюбів та 414 справ про стягнення аліментів [13]. Із цього випливає, що саме в судах першої інстанції щодо певних категорій справ доцільно було б запровадити обов'язкову судову медіацію. Процедурно це можна реалізувати у формі пілотного проєкту, зокрема, на етапі відкриття провадження у справі в ухвалі суду визначити терміни для обов'язкового звернення щодо передбачених законом категорій справ (розірвання шлюбу, аліменти, поділ майна, трудові, житлові спори) до судового медіатора. Після обов'язкової зустрічі в судового медіатора сторони визначають, бажають вони продовжити процес судової медіації чи переходять до підготовчого засідання й розгляду справи по суті.

Цікавим є досвід Грузії щодо питання покриття судових витрат: зі спорів, на які поширюється судова медіація, при поданні позову сплачується $1 \%$ від суми позову замість звичайних $3 \%$. Якщо за результатами процедури медіації спір не завершився угодою сторін, то позивач для продовження розгляду справи повинен доплатити до суми позову $2 \%$ від неї. Якщо судовий збір сплачено повністю і за умови, що процес судової медіації пройшов успішно, то 70 \% від сплаченої суми позову повертається позивачу [14, с. 156$]$.

3 погляду статистики обов'язкова медіація має перевагу через можливість отримання швидких результатів, дозволяє в найкоротші терміни зменшити кількість справ, які розглядаються судом за повною процедурою, що могло б позитивно вплинути на загальну тривалість розгляду справ і витрати судової системи. У рамках системи обов'язкової судової медіації простіше здійснювати контроль якості підготовки медіаторів і надання правової допомоги малозабезпеченим верствам населення.

Звичайно ж, необхідний спеціальний закон, який би визначав правові засади та порядок проведення судо- 
вої медіації, підготовку особи медіатора для якісного здійснення цієї процедури, статус медіатора і вносив відповідні зміни до цивільного процесуального законодавства. Однак це один із потенційно можливих механізмів, який би міг розв'язати цілу низку проблем цивільного судочинства.

ВИСНОВкИ. Упровадження інституту розв'язання спору за участю судді варто розцінити лише як перший законодавчий крок до формування альтернативних судових примирних процедур, який себе, на жаль, не виправдав. Цього не можна сказати про мирову угоду. Якщо в попередні роки здійснення мирових угод було чи не найбільш проблемним, то прийняття змін до ЦПК розв'язало чимало питань щодо їхньої правової регламентації та особливостей виконання. Тепер, коли в суді виникає питання укладення мирової угоди, найважливіше - подбати про те, щоб вона була максимально конкретна та її можна було виконати.

Список використаних джерел:

1. Цивільний процесуальний кодекс України // Відомості Верховної Ради України: кодекс від 18.03.2004, редакція від 23.05.2020. URL: https://zakon.rada.gov.ua/laws/show/1618-15.

2. Про медіацію: проект Закону України від 28.12.2019 № 2706. URL: http://w1.c1.rada.gov.ua/pls/zweb2/webproc4_1?pf3511=67831.

3. Ступак О. Найкращий спосіб вирішення спорів про поділ майна подружжя - укласти мирову угоду. URL: https://supreme.court.gov.ua/ supreme/pres-centr/news/953411/.

4. Цивільний процесуальний кодекс України: наук. практ. комент. / Й.Г. Богдан та ін.; за заг. ред. д-ра юрид. наук, проф., акад. Акад наук вищ. шк. України М.М. Ясинка. Київ: Правова єдність: Алерта, 2018. 602 с.

5. Романадзе Л.Ж. Врегулювання спору за участю судді та інші процесуальні новели: вплив на розвиток медіації. URL: http://mediation.ua/wp-content/uploads/2017/05/Stattya-pro-Mediatsiyu-vproektah-protses-kodeksiv-2.pdf.

6. Кіреєва НО., Приймак $€$ П. Проблемні аспекти проведення врегулювання спору за участі судді в цивільному процесі України. Вісник Київського національного університету імені Тараса Шевченка. Юридичні науки. 2018. Вип. 1 (106). С. 80-85.

7. Лесько А.О. Врегулювання спору за участю судді: проблеми і перспективи. URL: http://pd.onu.edu.ua/article/view/169533.

8. Кібенко О.Р. Судова медіація в господарському процесі - бути чи не бути? 18.02.2018. URL: https://censor.net.ua/blogs/3051121/sudova_ medatsya_v_gospodarskomu_protses_buti_chi_ne_buti.

9. Студенніков С. Врегулювання спору за участю судді: які проблеми показала практика. URL: http://www.judges.org.ua/ www.law.indiana.edu/dig16426.htm.

10. Бондаренко-Зелінська Н.Л. Врегулювання спору за участю судді: проблеми та перспективи застосування. Університетські наукові записки. 2018. № 3-4. С. 62-70. URL: http://nbuv.gov.ua/UJRN/ Unzap_2018_3-4_8.

11. Куйбіда Р.О. "Судочинна каламуть, або ще раз про реформу судового процесу" від 26.09.2017. URL: http://rpr.org.ua/news/ roman kuibida-sudochinna kalamut abo shche raz pro-html.

12. Смачило I. Досудове врегулювання конфлікту: чому світ зміг, а ми все ще ні. URL: https://nv.ua/ukr/biz/experts/dosudove-vregulyuvannyakonfliktu-yak-virishiti-spir-civilizovano-50024608.html.

13. Власюк К. Медіація в сімейних спорах. URL: https://yur-gazeta.com/publications/practice/simeyne-pravo/miris-miris-ibilshe-ne-svaris.html.

A. Kotsiuruba, PhD stud. (Law)

Taras Shevchenko National University of Kyiv, Kyiv, Ukraine
14. Запара C.I. "Перспективи судової медіаціїі в контексті альтерситих способів вирішення спору", 2017. URL: http://www.pplaw.in.ua/archive/3_2017/35.pdf.

\section{References:}

1. Cyvil'nyj procesual'nyj kodeks Ukrai'ny [Civil Procedural Code of Ukrai'ne]. Zakon Ukrai'ny (18.03.2004 No 1618-IV). Verkhovna Rada Ukrai'ny. URL: http://zakon3.rada.gov.ua/laws/show/1618-15 (in Ukr.).

2. Pro mediaciju: proekt Zakonu Ukrai'ny, 28.12.2019 No 2706. URL: http://w1.c1.rada.gov.ua/pls/zweb2/webproc4_1?pf3511=67831 (in Ukr.)

3. Stupak O. Najkrashhyj sposib vyrishennja sporiv pro podil majna podruzhzhja - uklasty myrovu ugodu. URL: https://supreme.court.gov.ua/ supreme/pres-centr/news/953411/ [in Ukr.].

4. Cyvil'nyj procesual'nyj kodeks Ukrai'ny [Tekst]: nauk. prakt. koment. / [J. G. Bogdan ta in.]; za zag. red. d-ra juryd. nauk, prof., akad. Akad nauk vyshh. shk. Ukrai'ny M. M. Jasynka. - Kyi'v: Pravova jednist' : Alerta, 2018. 602 s. [in Ukr.]

5. Romanadze, L.Zh. (2017). Vrehuliuvannia sporu za uchastiu suddi ta inshi protsesualni novely: vplyv na rozvytok mediatsii [Settlement of a dispute involving a judge and other procedural stories: influence on the development of mediation] / L.Zh. Romanadze. URL: http://mediation.ua/wpcontent/uploads/2017/05/Stattya-proMediatsiyu-v-proektah-protseskodeksiv-2.pdf [in Ukr.]

6. Kirejeva N.O., Pryjmak Je.P. Problemni aspekty provedennja vreguljuvannja sporu za uchasti suddi $v$ cyvil'nomu procesi Ukrai'ny [Problematic aspects of dispute resolution with the participation of a judge in the civil process of Ukraine] [Tekst] / N.O. Kirejeva, Je.P. Pryjmak. Visnyk Kyi'vs'kogo nacional'nogo universytetu imeni Tarasa Shevchenka. Jurydychni nauky. 2018. Vyp. 1 (106). S. 80-85 [in Ukr.]

7. Les'ko A.O. Vreguluvan'ya spory za ychastiy suddi: problemu I perspektuvi [Dispute settlement with the participation of a judge: problems and prospects]. URL: http://pd.onu.edu.ua/article/view/169533 [in Ukr.]

8. Kibenko O.R. Sudova mediacija $v$ gospodars'komu procesi - buty chy ne buty? [Judicial mediation in the economic process - to be or not to be?] 18.02.2018. URL: https://censor.net.ua/blogs/3051121/sudova_ medatsya_v_gospodarskomu_protses_buti_chi_ne_buti [in Ukr.]

9. Studennikov S. Vreguljuvannja sporu za uchastju suddi: jaki problemy pokazala praktyka [Settlement of a dispute with the participation of a judge: what problems did the practice show] URL: http://www.judges.org.ua/www.law.indiana.edu/dig16426.htm [in Ukr.].

10. Bondarenko-Zelins'ka N.L. Vreguljuvannja sporu za uchastju suddi: problemy ta perspektyvy zastosuvannja [Dispute settlement with the participation of a judge: problems and prospects of application]. Universytets'ki naukovi zapysky. 2018. №3-4. S. 62-70. URL: http://nbuv.gov.ua/UJRN/Unzap_2018_3-4_8 [in Ukr.]

11. Kujbida R.O. "Sudochynna kalamut', abo shhe raz pro reformu sudovogo procesu" vid 26.09.2017 [Judicial turmoil, or once again about judicial reform]. URL: http://rpr.org.ua/news/roman_kuibida-sudochinna_ kalamut_abo_shche_raz_pro-html [in Ukr.].

12. Smachylo I. Dosudove vreguljuvannja konfliktu: chomu svit zmig, a my vse shhe ni [Pre-trial settlement of the conflict: why the world could and we still can't]. URL: https://nv.ua/ukr/biz/experts/dosudove-vregulyuvannyakonfliktu-yak-virishiti-spir-civilizovano-50024608.html [in Ukr.].

13. Vlasjuk K. Mediacija $\vee$ simejnyh sporah [Mediation in family disputes]. URL: https://yur-gazeta.com/publications/practice/simeynepravo/miris-miris-i-bilshe-ne-svaris.html [in Ukr.].

14. Zapara S.I. "Perspektyvy sudovoi' mediacii'i' v konteksti al'ternatyvnyh sposobiv vyrishennja sporu" [Prospects for judicial mediation in the context of alternative dispute resolution], 2017. URL: http://www.pplaw.in.ua/archive/3 2017/35.pdf [in Ukr.].

Received: $30 / 04 / 2020$ 1st Revision: 06/06/2020 Accepted: $20 / 06 / 2020$

\section{CONCILIATION PROCEDURES IN CIVIL PROCEEDINGS IN UKRAINE}

The paper examines the legal nature and the regulatory grounds for two judicial conciliation procedures in civil proceedings, namely the amicable agreement and the procedure for dispute settlement with the participation of a judge.

Attention is drawn to the urgent need to study judicial conciliation procedures in civil proceedings of Ukraine. Their functional efficiency in the current conditions is assessed, some problematic aspects of the legislative regulation of these institutions are identified and proposals are made to eliminate shortcomings and possible reformatting of these procedures, which would probably contribute to the effective and rapid resolution of civil disputes.

It has been repeatedly emphasized that the development and use of conciliation procedures is a matter of the future for the entire justice system of Ukraine. The article determines the need to create a sufficient theoretical basis for the search for new or transformation of existing ways of regulating civil disputes, so that they solve the existing problems of the judicial system of Ukraine and contribute to the formation of "ideal justice".

A thorough analysis of the norms of the Civil Procedure Code of Ukraine governing the application of the amicable agreement and the dispute settlement procedure with the participation of a judge is carried out; a number of remarks and proposals to the current civil procedural legislation of Ukraine are expressed.

Possible ways of reformatting the legally defined mechanisms for resolving the dispute, which would partially or completely solve the tasks assigned by the legislator to judicial conciliation procedures, are proposed. Conclusions are formulated on the positive and negative phenomena caused by the reform of civil procedural legislation in terms of the conciliation procedures studied.

Keywords: civil proceedings, conciliation procedures, amicable agreement, settlement of a dispute with the participation of a judge, mediation, judicial mediation. 